\title{
KONFLIK DALAM PERNIKAHAN
}

\section{Maidiantius}

\section{Intisari}

Untuk mengatasi konflik pernikahan bukanlah suatu masalah yang mudah, jika kedua pasangan masih dikendalikan oleh keegoisan dan tidak mau melangkah maju, serta berusaha untuk memperbaiki konflik tersebut. tetapi konflik akan selesai jika pasangan suami isteri mau mengadopsi prinsip saling menerima dan saling memberi

\begin{abstract}
Konflik
Konflik merupakan masalah yang dapat menyebabkan pertengkaran, perselisihan atau benturan di antara kedua belah pihak, sehingga terjadi permusuhan. Jika konflik tidak diatasi dengan sedini mungkin dan dengan solusi yang baik, maka akan menimbulkan masalah yang jauh lebih parah dari pada sebelumnya. Konflik sering kali terjadi dalam pernikahan, sehingga menyebabkan pertengkaran dan perselisihan, apalagi pernikahan "pasang-an muda" selalu terjadi perbedaan-perbedaan yang tidak dipahami dan tidak diklarifikasi dengan baik, maka menimbul-kan konflik. Ada beberapa faktor penyebab konflik hubungan suami isteri:
\end{abstract}

\section{Perbedaan Latar Belakang}

Pertama, Pendidikan. Perbedaan ini sering kali ada di dalam lingkup pernikahan sekarang. Perbedaan pendidikan dalam membangun sebuah rumah tangga akan menjadi konflik jika kedua pribadi tidak memiliki pemahaman yang baik dan benar. Misalnya, seorang isteri memiliki level pendidikan S2, sementara suaminya hanya lulusan SMU. Jika kedua pribadi tidak saling mengerti dan memahami, maka akan ada pribadi yang mendominasi atau sebaliknya ada yang merasa minder.

Kedua, Status Sosial. Perbedaan status sosial pada umumnya selalu terjadi dalam pernikahan golongan tertentu. Misalnya, pernikahan dalam keluarga kaya atau keluarga yang masih mengakui tingkat-tingkat keturunan. Si suami mungkin dari keluarga kaya dan si istri dari keluarga yang tidak punya. Jika mereka tidak menciptakan suasana yang baik maka konflik akan muncul sama seperti pada konflik perbedaan pendidikan.

Ketiga, Hobby. Perbedaan hobby pun dapat memicu terjadinya konflik, bukan saja pada pasangan muda, tetapi juga sering terjadi pada pasangan yang sudah lama menikah.

Keempat, Pandangan atau Wawasan. Pada umumnya perbedaan ini sering terjadi yang pada akhirnya menimbulkan konflik. Si suami memiliki wawasan atau pandangan berdasarkan pengalaman dan pendidikannya, kemudian isteri memiliki pandangan yang berbeda. Masing-masing mempertahankan pandangannya, sehingga keadaan seperti jika tidak didasari oleh saling mengerti dan menerima maka akan menimbulkan konflik yang sangat parah dalam pernikahan.

Kelima, Adat-istiadat (suku). Adatistiadat tiap-tiap suku memiliki ciri khas tertentu, dan secara tidak langsung adatistiadat juga turut membentuk pribadi setiap orang yang bertumbuh di dalamnya.

\section{Perbedaan Kepribadian}

Konflik dalam pernikahan tidak hanya dipicu oleh perbedaan latar belakang, tetapi juga oleh perbedaan kepribadian. Membangun sebuah rumah tangga sangat penuh dengan tantangan, termasuk tantangan dari perbedaanperbedaan kedua belah pihak. Pada prin- 
sipnya bahwa dalam mencari pasangan hidup, jangan mencari yang cocok, tetapi belajarlah mencocokkan diri dengan pasangan, sehingga saling memperlengkapi. Perbedaan pada kepribadian akan menimbulkan konflik, jika prinsip saling menerima dan mengimbangi tidak diadopsi oleh suami dan isteri. Perbedaan kepribadian itu adalah gaya pribadi (dominan, intim, stabil, cermat), tipe pribadi (sanguin, plegmatik, melankolik, kolerik), orientasi pribadi (nonstrukturalstruktural, tugas orang).

Pernikahan adalah perpaduan emosi dua pribadi yang saling berfungsi, meskipun keduanya berbeda dan tetap memegang teguh jati-diri masing-masing. Namun mereka adalah satu kesatuan Two in one, yang pada prinsipnya tertulis dalam Kejadian 2:24, yaitu "Satu daging." Jika ada konflik dalam hubungan suami-isteri, yang utama adalah mencari akar penyebab dari konflik itu, misalnya, ketidakmampuan untuk menerima orang lain seperti apa adanya. Tidak mau mengampuni, kurangnya pengorbanan bagi pihak yang lain, dsb. Sebenarnya ini hanya masalah egoisme yang ada pada seseorang sehingga menimbulkan masalahmasalah tersebut. Solusi utama bagi pasangan suami istri dalam menyelesaikan semua ini yaitu naikkan doa syafaat bagi pasangan Anda, memuji Allah untuk apa yang akan Dia kerjakan dan belajarlah untuk saling menerima. Jika mungkin ajaklah pasangan Anda untuk berdoa bersama, karena jika kita sepakat meminta sesuatu maka Allah akan mengabulkannya. Matius 18:19, "Dan lagi Aku berkata kepadamu: Jika dua orang dari padamu di dunia ini sepakat meminta apapun juga, permintaan mereka itu akan dikabulkan oleh Bapa-Ku yang di sorga."

Pernikahan bukanlah suatu perjalanan hidup yang mudah, apalagi bagi pasangan anak-anak Tuhan, hal ini dapat dikatakan suatu perjuangan karena kehidupan kita di tengah masyarakat diperhadapkan dengan berbagai tantangan dan godaan. Di mana pun kita berada, kita dituntut untuk tetap konsisten pada pasangan. Kapan waktu salah satu pasangan tidak menjaga kesucian hubungan, maka hal itu akan menjadi jalan masuk bagi iblis untuk terus merongrong kehidupan kita masuk kepada jalannya. Oleh karena itu, seorang suami atau isteri harus selalu mendoakan pasangannya (saling mendoakan). Dan bagi pasangan yang menyakiti hatimu, tetaplah menampilkan sikap yang pengasih dan penyayang, karena sebagai murid Yesus kita diminta untuk serupa dengan Dia sebagai pengasih dan penyayang. Mazmur 103:8 "TUHAN adalah penyayang dan pengasih, panjang sabar dan berlimpah kasih setia."

Dalam keadaan tertentu, ada baiknya kita berdoa dan berpuasa untuk memohon pertolongan Tuhan atas konflik yang terjadi dalam pernikahan atau keluarga, berpuasa tidak selalu bertendensi kepada "tidak makan dan tidak minum". Berpuasa bisa punya arti luas; menahan emosi; menahan untuk tidak mengeluh; menahan kelakuan untuk menang sendiri dan lain-lain. Bila ada orang yang rela berpuasa untuk orang-orang yang terlibat masalah, bersyafaat dan berdiri di hadapan-Nya bagi saudaranya yang lemah, Allah berjanji untuk memberkati puasa itu dan memperbaiki kerusakan hubungan kita di dalam berkeluarga (Yesaya 58:6-12).

Penyelesaian atau jawaban dari konflik dalam pernikahan, bukanlah meninggalkan pernikahan atau perceraian, hadapi masalah tersebut dan mencari akan penyebabnya. Izinkan Tuhan Yesus untuk berkuasa dan memerintah dalam pernikahan, karena Yesus adalah satusatunya yang dapat merobohkan temboktembok kekerasan yang memisahkan suami dengan isteri dengan kasih-Nya. Efesus 2:14 "Karena Dialah damai sejahtera kita, yang telah mempersatukan kedua 
pihak dan yang telah merubuhkan tembok pemisah, yaitu perseteruan,"

\section{Menghindari Konflik: Thankful Heart}

Hati yang mengucap syukur hanya ada pada orang-orang yang memahami berkat yang sudah diterima dari Tuhan. Orang yang suka mengucap syukur, jarang terlibat dalam suatu konflik. Ibrani 13:15, "Sebab itu marilah kita, oleh Dia, senantiasa mempersembahkan korban syukur kepada Allah, yaitu ucapan bibir yang memuliakan nama-Nya."

Jangan bosan mengucapkan "terima kasih" pada hal-hal yang kecil sekalipun terhadap pasangan Anda, seperti ketika salah satu pasangan mengambilkan sesuatu untuk kita atau memberikan sesuatu. Kata Terima kasih adalah kalimat yang mempunyai pengaruh begitu besar yang dapat disebut sebagai magic words. Ucapan terima kasih itu membuat kita merasa lebih dihargai sehingga kita menjadi ingin melakukan lebih pada orang yang mengucapkannya. Jika kita ingin dihargai maka hargailah orang lain terlebih dahulu. Jika kita ingin dihormati maka hormatilah orang lain terlebih dahulu. Ini juga berlaku mutlak bagi pasangan kita dan menjadi prinsip hidup yang sangat mendasar.

\section{Mengatasi Konflik Pernikahan}

Untuk mengatasi konflik pernikahan bukanlah suatu masalah yang mudah, jika kedua pasangan masih dikendalikan oleh keegoisan dan tidak mau melangkah maju, serta berusaha untuk memperbaiki konflik tersebut. Tetapi konflik akan selesai, jika pasangan suami-isteri mau mengadopsi prinsip saling menerima dan saling memberi, dalam arti terbuka kepada pasangan, sehingga tindak lanjut untuk mengatasi konflik dapat dilakukan seperti langkah berikut:
Pertama, buatlah daftar sebanyak mungkin dari hal-hal yang dapat kita banggakan dari pasangan kita. Tiap-tiap hari menikmati bersama 5 dari hal-hal tersebut salama satu minggu sampai daftar itu habis. Dan berikanlah kritikan yang dapat membuat pasangan anda semakin baik, tetapi cara memberikan kritikan haruslah sesuai dengan situasi dan kondisi.

Kedua, membina komunikasi dan mendis-kusikan bersama tentang hal-hal apa yang menjadi harapan dan impian suami-istri terhadap keluarganya. Mungkin dimulai dengan membicarakan hal-hal umum seperti memilih rumah idaman, menata dekorasi rumah atau merencanakan anggaran biaya sekolah anak dsb. Semakin tinggi frekuensi pasangan melakukan diskusi dan saling berdialog, akan membuat hubungan menjadi lebih akrab. Mengapa hal seperti ini begitu penting? Setiap pasangan, bahkan yang paling berbahagia sekalipun, pasti akan melewati masa-masa sulit ketika mereka menemui ketidak-sepahaman dalam. memecahkan sebuah masalah. Dengan demikian, akan timbul perasaan dalam diri keduanya sebagai sebuah tim yang harus mencapai cita-cita, yakni mempertahankan keutuhan pernikahan.

Ketiga, usahakan selalu menghargai pendapat pasangan kita. Ketika saling bertukar- pikiran, jangan pernah saling menjatuhkan. Sebaliknya, ajang komunikasi tersebut dijadikan sarana untuk mengekspresikan rasa setia dan mempertebal komitmen serta memperkuat cinta. Jika hal itu terlaksana dengan baik, maka tiap-tiap pihak akan merasakan keuntungan hidup berumah tangga dan suatu kebahagiaan tersendiri. 
Masalah Pernikahan: "Perselingkuhan"

Hidup di dunia penuh tantangan dan godaan, tetapi hidup diciptakan bukan untuk menciptakan tantangan dan godaan. Arti hidup harus dipahami dengan benar, sehingga memperkecil ruang lingkup masalah yang timbul, baik bagi pribadi maupun keluarga. Masalah yang sering dialami dalam keluarga atau pasangan suami isteri adalah perselingkuhan. Perselingkuhan terjadi karena tidak ada komitmen dan konsistensi dalam pernikahan, sekalipun sudah meng-ucapkan janji pernikahan dan itu hanya sekadar ucapan belaka. Dalam kehidupan pernikahan, tidak ada orang yang suka dikhianati, demikian juga tidak ada yang merasa senang jika mengetahui pasangannya sedang berselingkuh. Allah sangat tidak setuju terhadap hal ini.

\section{Bagaimana Menghadapi Perselingkuhan?}

Pertama, jangan membiarkan diri dikuasai emosi sehingga melakukan halhal yang tidak baik atau bahkan lebih jauh melakukan tindakan melanggar hukum atau melakukan tindakan kriminal. Misalnya, karena suami diketahui berselingkuh, kemudian merijadi marah lalu melakukan tindakan pemukulan atau lebih dari itu.

Kedua, cobalah memahami bahwa setiap orang yang melakukan perselingkuhan, "tahu bahwa dirinya sedang berbuat dosa". Tidak peduli dia orang Kristen atau bukan, mereka tahu bahwa perselingkuhan itu salah. Sebab masalah ini juga merupakan pelanggaran norma yang berlaku di masyarakat.

Ketiga, menangkan kembali pasangan Anda untuk kembali dan mempunyai tanggung-jawab dalam rumah tangga. Maka apabila anda mendapati pasangannya sedang berselingkuh, janganlah memberikan judgement-judgement dengan kemarahan tak terkendali yang akan membuatnya lebih menjauhi Anda, hal ini yang kurang dipahami oleh banyak pasangan sehingga pada akhirnya bercerai. Tetapi berusahalah untuk meyakinkan pasangan Anda bahwa dia mempunyai tanggung jawab terhadap pernikahannya dan tanggung jawab terhadap anak-anaknya. Terlebih lagi tanggung jawab kepada Tuhan. Tunjukkan kasih kepada pasangan Anda bahwa kita inilah "yang paling special" untuknya, dan curahkan perasaan kita kepadanya. Bersikaplah bahwa Anda ini patut untuk dicintai, dan mudah untuk dicintai. Percayalah bahwa kemudian dia tidak akan pernah meninggalkan Anda, ini penting untuk membangun "konsep diri" dan selalu berusaha berpikir positif. Tentu saja, hal ini kadang sulit sekali untuk dilakukan; malah yang sering terjadi kita menjadi histeris dan sulit berpikir dengan kepala dingin.

Pada waktu kita mengalami masalah demikian, obat yang paling mujarab adalah "DOA", Tuhan adalah "konselor" terbaik, dan paling bijaksana. Dia tidak akan pernah membocorkan rahasia rumah tangga kita kepada orang lain. Kita melihat banyak contoh yang dilakukan Raja Daud, dia sering melepaskan kehancuran hatinya di hadapan Tuhan. Kadang ada baiknya melakukan "sharing dan mengungkapkan keluhkesah" kepada sahabat-sahabat kita; mereka bisa menjadi the shoulder to cry on, tetapi ada buruk-nya juga; bahwa gossip rumah tangga sering bocor dari mulut seorang teman, dan kadang malah berdampak buruk.

\section{Mengapa Bisa Terjadi Perselingkuhan?}

Perselingkuhan terjadi karena kita membiarkan hati kita untuk dicobai atau karena kita menciptakan peluang bagi perselingkuhan tersebut. Bagaimanakah dosa itu lahir? Bagaimanakah kita berkomunikasi? Yakobus 1:14-15, "Tetapi tiap-tiap orang dicobai oleh keinginannya 
sendiri, karena ia diseret dan dipikat olehnya. Dan apabila keinginan itu telah dibuahi, ia melahirkan dosa; dan apabila dosa itu sudah matang, ia melahirkan maut. Seseorang yang berselingkuh, dia sedang ada dalam accident kecelakaan terhadap suatu komitmen. Kita tahu kadang-kadang kecelakaan terjadi akibat sikap teledor dan kesengajaan. Yakobus mengatakan "Dia dicobai oleh keinginannya sendiri, terseret dan terpikat olehnya". Getaran akibat perasaan "cinta" terhadap lawan jenis yang tidak semestinya, kadang memang sulit dibendung. Kadang pesonanya mengaburkan segala komitmen dan pengetahuan tentang kebenaran. Dan setiap orang tidak terkecuali orang baik-baik, rohaniawan, berpendidikan atau tidak, kaya, miskin, semuanya punya potensi mengalami accident ini.

Menurut Psikolog, Darmanto Jatman, "Apabila istrimu menceritakan figur rekan laki-lakinya dengan perasaan kagum lebih dari 3 kali sehari, tolonglah dia sebab dia sedang jatuh cinta". Perselingkuhan timbul karena ada kecocokan dalam berdialog, yang utama ketika mereka menemukan kecocokan ini, maka sangat berbahaya yang dapat berlanjut ke jenjang yang lebih dalam dan akan susah mengakhirinya. Perselingkuhan yang didasari oleh pemenuhan kebutuhan emosi (jiwa) lebih susah diakhiri daripada perselingkuhan yang hanya didasari oleh hasrat seksual. Namun perselingkuhan tidak selalu berkonotasi "kontak seksual". Perselingkuhan bisa menimpa siapa saja dan ternyata, menangkal pernik-pernik perselingkuhan tidak semudah yang kita duga, karena godaannya cukup besar. Tuhan Yesus memberikan peringatan sbb: Matius 5:27-28, "Kamu telah mendengar firman: Jangan berzinah. Tetapi Aku berkata kepadamu: Setiap orang yang memandang perempuan serta menginginkannya, sudah berzinah dengan dia di dalam hatinya."
Definisi perselingkuhan adalah "hubungan pribadi di luar nikah, yang melibatkan sekurangnya satu orang yang berstatus nikah", dan didasari oleh tiga unsur: (1) Saling ketertarikan (2) Saling ketergantungan (3) Saling memenuhi secara emosional dan seksual.

Kata "berselingkuh" dalam Kamus Bahasa Indonesia berarti curang atau tidak jujur, atau tidak berterang-terangan, atau corrupt, sering kali kita tidak menyadari bahwa berselingkuh adalah satu perkara yang tidak berkenan kepada Allah.

Ketika kita menghadapi kenyataan bahwa pasangan kita berselingkuh, jangan cepat-cepat menghakiminya dengan rentetan cacian, hujatan dan kemarahan yang bertubi-tubi. Pahami dia sedang mengalami accident yang harus segera "ditolong" untuk lepas dari jeratannya. Pahamilah mengapa dia berselingkuh, adakah kekurangan kita, adakah kesalahan-kesalahan yang tidak sengaja kita lakukan terhadapnya, atau mungkin kita mengabaikan kebutuhannya sekian lama. Hati yang lapang dan sikap pengampunan sangat diperlukan untuk pengobatannya. Sadari bahwa Andalah tokoh utama penyelamat pernikahanmu, bukan pihak ketiga (pendeta, saudara, orang tua, temanteman, dll.) dan pasangan Anda adalah harta milikmu.

Pahamilah bahwa adakah hal-hal yang tidak bisa dia bagikan (sharingkan) denganmu? Apakah dia nyaman ketika menceritakan tentang urusan pekerjaannya denganmu? Apakah anda menjadi pendengar yang baik setiap kali dia berkeluhkesah? Apakah anda bisa menjadi penolong yang diandalkan dalam menghadapi kesulitan yang dihadapi. Ketika tidak ada kecocokan dalam dialog suami-isteri maka di sinilah awal timbulnya keretakan. Sering kali seorang suami memendam sendiri urusannya dan tidak mau menceritakannya kepada isterinya karena yakin jika isterinya tahu, dia akan marah besar. Kadang hal ini bisa menumpuk dan 
membuatnya penat, dan bahayanya jika suami bertemu dengan seorang wanita yang bisa menjadi pendengar yang baik, maka di situlah awal perselingkuhan itu.

Fungsi isteri adalah menjadi penolong yang setia maka ini harus selalu diingat, agar istri benar-benar menjadi pribadi yang patut dipuja oleh sang suami. Demikian juga sebaliknya seorang suami bisa mengabaikan fungsinya, sehingga istri mungkin lebih suka curhat ke rekan-rekan lainnya. Lebih nyaman berbagi airmata kepada orang lain daripada suaminya sendiri. Ini akan menimbulkan dampak yang tidak baik. Kasihilah pasanganmu dengan jiwamu, ungkapkan itu terus-menerus kepadanya. Supaya dia senantiasa ingat bahwa dia memiliki harta yang hebat di rumah. Ucapkan kata "aku mengasihimu atau I love you" setiap hari. Peluk dia dengan kasih, bicaralah dengan bahasa yang sopan dan lembut, hargai setiap pendapatnya, hormati dia, maka dia tidak akan pernah meninggalkan Anda. Ungkapan dari Lenny Cohen mengatakan, "I love you everyday, and twice on Sunday" kedengarannya lucu, tetapi indah didengar, bukan?!

Seks adalah sarana kasih dalam pernikahan, walaupun bisa dikatakan sebagai "kebutuhan-wajib", tetapi terlebih penting adalah relationship suami-isteri. Binalah kecocokan antara Anda dan pasanganmu. Kasih itu tidak hanya dimulut. Sebagai contoh; seorang suami mengasihi istri pun dikatakan seperti mengasihi diri sendiri, tidak mungkin kita akan menghancurkan diri sendiri, atau menghancurkan tubuh sendiri. Dengan kata lain, jika kita merusak penikahan artinya kita merusak tubuh sendiri (suamiisteri adalah satu tubuh). Kristus adalah kepala dari jemaat, suami adalah kepala dari rumah tangga, bagaimana menyatakan kasihnya, saling menyatakan timbal balik dalam perbuatan yang nyata, sekali lagi karena ini adalah kehendak Allah:
Efesus 5:28-32, "Demikian juga suami harus mengasihi isterinya sama seperti tubuhnya sendiri: Siapa yang mengasihi isterinya mengasihi dirinya sendiri. Sebab tidak pernah orang membenci tubuhnya sendiri, tetapi mengasuhnya dan merawatinya, sama seperti Kristus terhadap jemaat, karena kita adalah anggota tubuh-Nya."

Tubuh kita adalah bait Allah, mari kita pelihara bait suci Allah ini. Kekacauan akibat perselingkuhan akan mempengaruhi kehidupan keluarga kita. Seorang anak tidak bisa menghormati orangtuanya jika mereka tahu orang-tuanya melakukan perselingkuhan. Sebagai akibat dari apa yang diperbuat orang tuanya, kekacauan ini akan berpengaruh terhadap kesehatan emosional anakanaknya, misalnya satu fakta yang tertulis dalam Alkitab bagaimana Absalom tidak pernah bisa hormat kepada Daud ayahnya, karena dia tahu ayahnya berselingkuh dengan Betsyeba. Absalom menjadi sosok yang memberontak bapaknya sendiri sampai akhir hayatnya. Inilah kedahsyatan Alkitab, yang selalu jujur menulis kehidupan para nabi. Ini dimaksudkan sebagai pembelajaran dan contoh yang harus dihindari bagi umat Tuhan selanjutnya.

\section{Menjaga Pernikahan Tetap Harmonis}

Seorang ibu tidak akan pupus perasaan cintanya kepada anak-anaknya, tetapi dia bisa kehilangan rasa cintanya kepada suaminya. Kenyataan ini lazim ditemui, padahal kita tinggal serumah selama-lamanya dengan suami atau isteri kita sampai kematian menjemput. Saat anak-anak kita beranjak dewasa dan menikah kita pun tetap tinggal bersama dengan suami atau istri. Maka di sinilah pentingnya pembinaan hubungan suamiistri untuk tetap harmonis, karena you're going to live with him/her forever. Jadikanlah suami atau isteri kita itu soul mate atau "pasangan jiwa" yang tidak terpisahkan. Langkah-langkah menjadikan pernikahan tetap harmonis, yaitu; 
Pertama, Waktu Berdua. Salah satu persoalan terbesar dalam perkawinan saat ini adalah kurangnya waktu bersama. Pasangan yang berbahagia selalu mengatur jadwal mereka untuk dapat meluang waktunya bersama, setidaknya seminggu sekali. Walaupun sudah lama menikah, namun tetap memerlukan waktu khusus untuk ber-duaan, seperti pada waktu masamasa pertama jatuh cinta dulu. Sayang sekali jika hal ini susah dilakukan diakibatkan kesibukan urusan rumahtangga yang rutin, urusan anak dan sebagainya. Kadang-kadang perlu sesekali dilakukan dengan makan malam berdua, berjalan-jalan berdua untuk tetap menjaga bahwa hubungan kedua orang yang sudah menjadi suami isteri itu tetap akrab. Sebab pernikahan yang sudah lama akan lambatlaun mematikan "rasa cinta" mula-mula seperti saat berpacaran dulu, sehingga sering kita mendengar keluhan tentang "pernikahan hambar".

Kedua, Saling Percaya dan Menghargai. Ketika suami-isteri saling percaya dan menghargai, artinya mereka telah mencapai "titik" damai di dalam keluarga. Percaya, artinya kita mempunyai harapan, percaya bahwa suami mampu melakukan pekerjaan besar, percaya dia akan tetap setia dsb. Demikian juga sikap suami terhadap istri, menaruh kepercayaan bahwa dia mampu melakukan tugas-tugas rumah tangga, mendidik anak, melakukan pekerjaan, tetap setia dsb. Sikap percaya ini akan mendatangkan kedamaian. Ketika kita menghargai seseorang, itu juga akan tercermin dari tutur kata kita yaitu akan berbicara dengan lembut dan sopan. Hendaknya kita juga selalu bertutur kata sopan dan lembut kepada pasangan kita sebagai wujud penghargaan dan kasih. Suami dan istri adalah makhluk yang berharga di mata Allah.

Ketiga, Saling Memaafkan. Kita harus menjaga hati kita masing-masing, agar setiap konflik yang kita hadapi tidak berlanjut kepada hal-hal yang lebih buruk.
Amsal 4:23, "Jagalah hatimu dengan segala kewaspadaan, karena dari situlah terpancar kehidupan." Saat kita memaafkan kesalahan seseorang, saat itu juga kita berdamai dengan seseorang yang membuat kita jengkel, marah dan kecewa. Janganlah pernah menyimpan kekesalan dan kemarahan terhadap pasangan kita sampai berhari-hari, bicara-kan dan capailah titik temu kesepakatan jika mengalami konflik dan memaafkan kesalahan yang dibuat pasangan kita. Saling memaafkan di dalam keluarga akan membuat keutuhan semakin kuat dan kebahagiaan semakin terasa. "Kita tidak akan pernah berhasil, jika kita tidak berusaha untuk mencoba, dengan sepenuh hati" $^{\prime \prime}$

\section{Kepustakaan}

Tim \& Beverly La Haye, Kehidupan Seks dalam Pernikahan, Bandung: Kalam Hidup, 1998.

Pola Hidup Kristen (Penerapan Praktis), Bandung: $\mathrm{KH}$, Malang: GM, Bandung:Lembaga Literatur Baptis, Surabaya: Yakin, 2002.

Yusuf Roni, Membina Keluarga Kristen

Bahagia, Yogyakarta: ANDI, 1996.

Norman H. Wright, Komunikasi Kunci

Pernikahan Bahagia 2, Yogyakarta:

Yayasan Gloria, 2000.

Kenneth Barney, Rumah Tangga Kristen, Malang: Gandum Mas, 1997.

Evelin Christenson, Mengatasi Perselisihan-

Perselisihan dalam Keluarga, Malang:

Gandum Mas, 1987. 